\title{
ReSEARChArTicle
}

\section{Impact of integrated weed management on yield and economics of Kharif maize (Zea mays L.)}

\author{
A. S. Bade, J. B. Patil, P. N. Gajbhiye, I. Sarwar and Kiran Yadav
}

\section{SUMMARY}

A field experiment conducted to evaluate the impact of integrated weed management on economics of Kharif maize (Zea mays L.) during Kharif, 2020 at Post Graduate Research Farm, RCSM College of Agriculture, Kolhapur. The field experiment was laid out in Randomized Block Design (RBD) having eight treatments replicated thrice. Weed free check and tank mixure application of Tembotrinone 42 SC@120gm a.i.ha ${ }^{-1}+$ Atrazine 50 WP @ 500 gm a.i.ha ${ }^{-1}+$ surfactant @ 2ml/1 of water EPoE At 20-25 DAS + fb hand weeding at 40 DAS were on par with each other and recorded significantly increase in grain and straw yields of maize as compared to remaining weed management treatments. Significantly lowest values for yield and yield attributes was observed in weedy check treatment.Maximum gross monetary returns and net monetary returns were observed in weed free check treatment was Rs. $183225.5 \mathrm{ha}^{-1}$ and Rs. $126320.7 \mathrm{ha}^{-1}$, respectively. Tank mixure

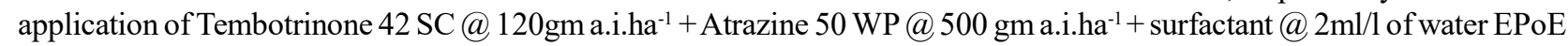
At 20-25 DAS recorded maximum B: C ratio (3.34).

Key Words : Weed,Tembotrione, Tank mixture, Weed dry weight, Topramezone etc.

How to cite this article : Bade, A. S., Patil, J. B., Gajbhiye, P. N., Sarwar, I. and Yadav, Kiran (2021). Impact of integrated weed management on yield and economics of Kharif maize (Zea mays L.). Internat. J. Plant Sci., 16 (AAEBSSD): 73-76, DOI: 10.15740/ HAS/IJPS/16.AAEBSSD/73-76, Copyright@ 2021: Hind Agri-Horticultural Society.

Article chronicle : Received : 10.07.2021; Revised : 13.07.2021; Accepted : 20.07.2021

\section{MEMBERS OF THE RESEARCH FORUM}

Author to be contacted :

J.B. Patil, Department of Agronomy, RCSM College of Agriculture, Kolhapur (M.S.) India

Email : patiljb1976@gmail.com

Address of the Co-authors:

A.S. Bade and P.N. Gajbhiye, RCSM College of Agriculture, Kolhapur (M.S.) India

I. Sarwar, Department of Agronomy, RCSM College of Agriculture, Kolhapur (M.S.) India

$\overline{\text { Kiran Yadav, College of Agriculture, Kadegaon, Sangali (M.S.) India }}$
$\mathrm{M}$ aize belongs to the family of grasses (Poaceae). It is cultivated globally being one of the most important cereal crops worldwide. Maize is not only an important food crop for human consumption, but also a basic element used as animal found raw material for manufacturing of many industrial products. The products include corn starch, maltodextrins, corn oil, corn syrup, and products of fermentation and distallaries. It is also being recently used in the production of biofuel. Maize can be grown successfully in variety of soils ranging from loamy sand to clay loam. However, 
soils with good organic matter content having high water holding capacity with neutral PH are consider good for higher productivity.

Among the maize growing countries India rank $4^{\text {th }}$ in area and $7^{\text {th }}$ in production, representing around $4 \%$ of world maize area and 2\% of total production. During 2018-19 in India, the maize area has reached to 9.2 Mha (DACNET, 2020). During 1950-51 India used to produce 1.73 million MT maize, which has increased to 27.8 million MT by $2018-19$, recording close to 16 times increase in production. The average productivity during the period has increased by 5.42 times from $547 \mathrm{~kg} \mathrm{ha}^{-1}$ to $2965 \mathrm{~kg} \mathrm{ha}^{-1}$ while area increased nearly by three times. Though the productivity in India is almost half of world the average per day productivity of Indian maize is at par with many lead maize producing countries. In India, maize is principally grown in two seasons, rainy (Kharif) and winter (Rabi) Kharif maize represents around $83 \%$ of maize area in India, while Rabi maize correspond to $17 \%$ maize area. Over $70 \%$ of Kharif maize area is grown under rainfed condition with prevalence of many biotic and abiotic stresses. Among Indian states Madhya Pradesh and Karnataka has highest area under maize (15\% each) followed by Maharashtra (10\%), Rajasthan (9\%), Uttar Pradesh (8\%) and others. After Karnataka and Madhya Pradesh Bihar is the highest maize producer. Andhra Pradesh is having highest state productivity. Some districts like Krishna, West Godavari etc records a high as $12 \mathrm{tha}^{-1}$ productivity.

Low yield of maize under Indian conditions may be attributed due to number of factors, among them weeds rank as prime enemy. Maize being a rainy season crop and sown at wider spacing coupled with slow initial growth resulted in heavy weed infestation. Hand weeding is the commonest and effective method of control of weeds, however, it is not only intensive, but also expensive and strenuous. Frequent and heavy rainfall during Kharif season, unavailability of human labour at peak agricultural operations and inflated labour wages coupled with unfavourable soil physical conditions for intercultural operations forcing the farmers for chemical weed control in maize. The extent of yield loss due to weeds in maize varies from 28 to 93 per cent depending on the type of weed flora, intensity and duration of crop weed competition. Chemical weed management is the viable option in maize crop as highly selective post-emergence herbicides are available in India the presence of weeds, in general reduces the maize yield by 27 to $60 \%$ depending upon the growth and persistence of weed population in maize crop (Kumar et al., 2015) However, Yakadri et al., 2015 opined that wider spacing and initial slow growth of maize during the first 3-4 weeks to invade and offer severe competition, resulting in 30-93\% yield losses. Weeds are causing serious problem in maize whatever the climatic conditions are, some dominant weed species in maize were Polygonumpersicaria, $P$. pensylvanicum, $P$. orientale, Oldenlandiadiffusa, Oldenlandia aquatic, Oxalis corniculata, Stellaria media, Stellaria aquatic, Physalis minima, Solanum nigrum, Hydrocotylranunculoides, Ageratum conyzoides (appeared at latter part of crop growth), the sedge like Cyperus rotundus and the grasses like Cynodondactylon, Digitariaciliaris, Setariaglauca, Echinochloa sp. Among these weeds Polygonum sp., Cynodondactylon, Digitariaciliaris, Setariaglauca were highly aggressive in maize.

\section{MATERIAL AND METHODS}

The experiment was laid out in a Randomized Block Design during Kharif 2020 at the Post Graduate Research Farm, RCSM College of Agriculture, Kolhapur with twelve treatments. Each experimental unit was replicated thrice with the gross and net plot size of $5.0 \mathrm{x}$ $4.5 \mathrm{~m}^{2}$ and $3.8 \times 3.0 \mathrm{~m}^{2}$, respectively. The soil of the experimental plot was medium black clay (vertisol) with $90 \mathrm{~cm}$ depth, low in available $\mathrm{N}\left(250 \mathrm{~kg} \mathrm{ha}^{-1}\right)$, high in available $\mathrm{P}_{2} \mathrm{O}_{5}\left(30.60 \mathrm{~kg} \mathrm{ha}^{-1}\right)$ and medium in available $\mathrm{K}_{2} \mathrm{O}\left(290.67 \mathrm{~kg} \mathrm{ha}^{-1}\right)$. The status of organic carbon content $(0.34 \%)$ was low. The electrical conductivity and $\mathrm{pH}$ values were $0.30 \mathrm{dSm}^{-1}$ and 7.10, respectively. The treatment consisted of $\mathrm{T}_{1}$ : Atrazine 50 WP@1000 gm a.i. ha ${ }^{-1} \mathrm{PE}$ at 3-5 DAS, $\mathrm{T}_{2}$ : Topramezone 33.6 SC @ 25.2 gm a.i.ha $^{-1}+$ surfactant (MSO adjuvant@2ml/1 of water EPoE at 20-25 DAS, T : Tembotrinone 42 SC @ 120 gm a.i.ha ${ }^{-1}+$ surfactant @2ml/1 of water EPoE at 20-25 DAS, $\mathrm{T}_{4}: \mathrm{T}_{1}+\mathrm{fb}$ HW at 40 DAS, $\mathrm{T}_{5}: \mathrm{T}_{2}+\mathrm{fb} \mathrm{HW}$ at $40 \mathrm{DAS}, \mathrm{T}_{6}: \mathrm{T}_{3}+\mathrm{fb} \mathrm{HW}$ at $40 \mathrm{DAS}, \mathrm{T}_{7}$ : Topramezone 33.6 SC @25.2 gm a.i.ha ${ }^{-1}+$ Atrazine 50 WP @ 500 gm a.i.ha ${ }^{-1}+\mathrm{S}$ (MSO adjuvant@2ml/1 of water EPoE at 20-25 DAS, T: Tembotrinone 42 SC@120 gm a.i.ha ${ }^{-1}$ + Atrazine 50 WP@500 gm a.i.ha ${ }^{-1}+$ Surfactant @ $2 \mathrm{ml} / 1$ of water EPoE at 20-25DAS, $\mathrm{T}_{9}: \mathrm{T}_{7}+\mathrm{fb} \mathrm{HW}$ at 40 DAS, $\mathrm{T}_{10}: \mathrm{T}_{8}+\mathrm{fb}$ HW at $40 \mathrm{DAS}, \mathrm{T}_{11}:$ Weed free check up to $60 \mathrm{DAS}, \mathrm{T}_{12}$ : Weedy check. On the basis of yield and current market price of produce, economics will be calculated for each net treatment plot on $\mathrm{ha}^{-1}$ basis. Cost 
of cultivation, gross monetary returns, net monetary returns and $\mathrm{B}$ : $\mathrm{C}$ ratio of each treatment plot calculated.

\section{RESULTS AND DISCUSSION}

Mean data on grain and straw yield, cost of cultivation, gross and net monetary returns and benefit cost ratio influenced by different weed management treatments are showed in Table 1.

\section{Grain and straw yield:}

Higher grain and straw yield was recorded in weed free check treatment i.e., (75.25 q ha-1) and (101.58 q $\mathrm{ha}^{-1}$ ), respectively. Among herbicidal treatments maximum grain and straw yield was recorded in Tank mixture application of Tembotrinone 42 SC @ 120gm a.i.ha ${ }^{-1}+$ Atrazine 50WP@500 gm a.i.ha ${ }^{-1}+$ @2ml/1 of water EPoE At 20-25 DAS fb HW at 40 DAS i.e., 73.90 $\mathrm{q} \mathrm{ha} \mathrm{h}^{-1}$ and $99.77 \mathrm{q} \mathrm{ha}^{-1}$, respectively. The next best treatments were Topramezone 33.6 SC @25.2 gm a.i.ha ${ }^{-1}+$ Atrazine 50 WP @ 500 gm a.i.ha ${ }^{-1}+$ (MSO adjuvant@2ml/1 of water EPoE At 20-25 DAS fb hand weeding at 40 DAS, Tembotrinone42 SC @120gm a.i.ha ${ }^{-1}+$ Atrazine 50 WP @ 500 gm a.i.ha $^{-1}+$ surfactant $2 \mathrm{ml} / 1$ of water EPoE at 20-25DAS and Topramezone 33.6 SC@25.2 gm a.i.ha ${ }^{-1}+$ Atrazine 50 WP@500 gm a.i.ha-1 + (MSO adjuvant@2ml/1 of water EPoE at 20$25 \mathrm{DAS}$. These treatments recorded maximum grain and straw yield compared to sole application of Tembotrione and Topramezone herbicide. Grain and straw yield of maize was significantly lower in weedy check treatment i.e., $35.66 \%$ and $50.31 \%$, respectively. The highest grain yield was obtained under weed free check treatment due to less crop- weed competition throughout the crop growth period, thus enabling the crop for maximum utilization of nutrients, water, nutrients, light and space which favoured higher yield contributing characters. These results were also given by Swetha et al. (2015), Umesh et al. (2015) and Parul et al. (2017).

\section{Gross monetary return:}

Gross monetary returns were significantly influenced by various weed management treatments. Maximum gross monetary returns were observed in weed free check treatment (Rs.183225.5 ha' ${ }^{-1}$ ) and it was followed by $\mathrm{T}_{10}$ treatments. While the lowest gross monetary returns was observed in weedy check (Rs. $\left.87925.1 \mathrm{ha}^{-1}\right)$. Due to effective weed control in weed free check, it reduced the weed crop competition as a result vigorous crop growth was obtained which resulted in to higher yield as well as gross monetary returns.

\section{Net monetary returns:}

The net monetary returns were significantly influenced by different treatments. The highest net monetary returns were observed in weed free check (Rs. $126320.7 \mathrm{ha}^{-1}$ ). However, the lowest net monetary

\begin{tabular}{|c|c|c|c|c|c|}
\hline Treatments & $\begin{array}{c}\text { Grain yield } \\
\left(\mathrm{q} \mathrm{ha} \mathrm{h}^{-1}\right)\end{array}$ & $\begin{array}{c}\text { Straw yield } \\
\left(\mathrm{q} \mathrm{ha}^{-1}\right)\end{array}$ & $\begin{array}{l}\text { Gross monetary } \\
\text { returns }\left(\text { Rs. ha }^{-1}\right)\end{array}$ & $\begin{array}{l}\text { Net monetary returns } \\
\left.(\text { Rs. ha })^{-1}\right)\end{array}$ & $\begin{array}{l}\mathrm{B}: \mathrm{C} \\
\text { ratio }\end{array}$ \\
\hline $\mathrm{T}_{1}$ & 54.08 & 76.96 & 133661.9 & 86456.29 & 2.83 \\
\hline $\mathrm{T}_{2}$ & 59.64 & 80.51 & 145213.7 & 96440.05 & 2.97 \\
\hline $\mathrm{T}_{3}$ & 60.22 & 81.30 & 146637.3 & 98535.71 & 3.04 \\
\hline $\mathrm{T}_{4}$ & 62.85 & 84.85 & 153043.8 & 92734.19 & 2.53 \\
\hline $\mathrm{T}_{5}$ & 64.61 & 87.22 & 157314.8 & 98349.18 & 2.66 \\
\hline $\mathrm{T}_{6}$ & 65.10 & 89.59 & 159373.4 & 102535.8 & 2.8 \\
\hline $\mathrm{T}_{7}$ & 65.34 & 92.03 & 161008.4 & 111450.8 & 3.24 \\
\hline $\mathrm{T}_{8}$ & 66.04 & 94.56 & 163506.1 & 114620.5 & 3.34 \\
\hline $\mathrm{T}_{9}$ & 72.09 & 97.32 & 175537.7 & 118700.1 & 3.08 \\
\hline $\mathrm{T}_{10}$ & 73.90 & 99.77 & 179951 & 125241.4 & 3.28 \\
\hline $\mathrm{T}_{11}$ & 75.25 & 101.58 & 183225.5 & 126320.7 & 3.21 \\
\hline $\mathrm{T}_{12}$ & 35.66 & 50.31 & 87925.1 & 42668.28 & 1.94 \\
\hline $\mathrm{F}$ test & Sig & Sig & Sig & Sig & - \\
\hline S.E. \pm & 2.86 & 3.85 & 1919.11 & 2406.18 & - \\
\hline C.D. $(\mathrm{P}=0.05)$ & 8.42 & 11.30 & 5757.33 & 7218.55 & - \\
\hline General mean & 62.89 & 86.33 & 153866.6 & 101171.1 & 2.91 \\
\hline
\end{tabular}


returns were observed in weedy check (Rs. 42668.28 $\left.\mathrm{ha}^{-1}\right)$. These results were also given by Barad et al. (2016), Dharam et al. (2018) and Dobaria et al. (2015).

\section{Benefit: cost ratio:}

Benefit: cost ratio was influenced by various treatments. The highest benefit cost ratio was observed in Tembotrinone 42 SC@120gm a.i.ha ${ }^{-1}+$ Atrazine 50 WP@ 500 gm a.i.ha ${ }^{-1}+$ surfactant @ 2 ml/1 EPoE at 20-25DAS followed by Tembotrinone42 SC @120gm a.i.ha ${ }^{-1}+$ Atrazine 50 WP@ 900 gm a.i.ha $^{-1}+$ surfactant (a) $2 \mathrm{ml} / 1$ of water EPoE At 20-25 DAS + fb hand weeding at 40 DAS. This might be due to more grain and straw yield and low cost of cultural and herbicidal weed control in this treatment. These results are closely in conformity with finding of Arvadia et al. (2012).

\section{Conclusion:}

Tembotrinone 42 SC@120gm a.i.ha ${ }^{-1}+$ Atrazine 50 WP@500 gm a.i.ha ${ }^{-1}+$ surfactant@2ml/1 of water EPoE at 20-25DAS proved to be more remunerative treatment in producing maximumB:C ratio in maize.

$\mathrm{T}_{1}$ : PE application of Atrazine 50\%WP@ 1000 a.i.ha ${ }^{-1} \mathrm{PE}$ at 3-5 DAS, $\mathrm{T}_{2}$ : Topramezone33.6 SC@25.2 gm a.i.ha ${ }^{-1}+$ surfactant (MSO adjuvant@2ml/1 of water EPoE at 20-25 DAS, T 3 : Tembotrinone42 SC@120gm a.i.ha ${ }^{-1}+$ surfactant @2ml/1 of water EPoE at 20-25 DAS, $\mathrm{T}_{4}: \mathrm{T}_{1}+\mathrm{HW}$ at $40 \mathrm{DAS}, \mathrm{T}_{5}: \mathrm{T}_{2}+\mathrm{fb} \mathrm{HW}$ at 40 DAS, $\mathrm{T}_{6}: \mathrm{T}_{3}+\mathrm{fb} \mathrm{HW}$ at $40 \mathrm{DAS}, \mathrm{T}_{7}:$ Topramezone 33.6SC@25.2 gm a.i.ha ${ }^{-1}+$ Atrazine 50WP@500 gm a.i.ha ${ }^{-1}+$ surfactant (MSO adjuvant@2ml/1 of water EPoE at 20-25 DAS, $\mathrm{T}_{8}$ : Tembotrinone42 SC @ 120gm a.i.ha ${ }^{-1}+$ Atrazine 50 WP@ 900 gm a.i.ha $^{-1}+$ surfactant @ 2 $2 \mathrm{ml} / 1$ of water EPoE at 20-25DAS , $\mathrm{T}_{9}: \mathrm{T}_{7}+\mathrm{fb} \mathrm{HW}$ at $40 \mathrm{DAS}, \mathrm{T}_{10}: \mathrm{T}_{8}+$ fb HW at $40 \mathrm{DAS}, \mathrm{T}_{11}$ : weed free check, $\mathrm{T}_{12}$ : Weedy check.
The authors are thankful to Agronomy Section, RCSM College of Agriculture, Kolhapur - 416004, Maharashtra, India for providing necessary facilities to undertake the field experiment.

\section{REFERENCES}

Aruna, K. J., Rao, P. C., Madhavi, M. and Padmaja, G. (2018). Effect of herbicides on the activity of soil enzyme urease in maize crop.Indian Journal of Agricultural Research, 52 (3) : 300- 304.

Barad, B., Mathukia, R.K., Gohil, B.S. and Chhodavadia, S.K. (2016). Integrated weed management in rabi popcorn (Zeamaysvar. everta). Journal of Crop\& Weed.,12(1): 150-153.

Dharam, B.Y., Ashok, Y., Punia, S.S. and Anil, D. (2018). Tembotrione for post emergence control of complex weed flora in maize. Indian Journal of Weed Science, 50 (2): 133-136.

Dobariya, V. K., Mathukia, R. K., Gohil, B.S. and Shivram, A. (2015). Integrated weed management in Rabi sweet corn (Zea mays var.Saccharata). Journal of Ecofriendly Agriculture, 10 (1) : 70-83.

Parul, K., Tiwari, A.R., Sharma and Bhambri, M.C. (2017). Biennieal Conference of the Indian Science on "Doubling Farmers Income by 2022: The role of weed Science", MPUA and T, Udaipur, India during 1-3 March, pp. 227.

Swetha, K., Madhavi, M., Pratibha, G. and Ramprakash, T. (2015). Weed management with new generation herbicides in maize. Indian Journal of Weed Science, 47 (4): 432-433.

Umesha, C., Sridhara, S. and Aswini (2015). Effect of pre and post emergent herbicides on growth, yield parameters and weed control efficiency in maize ( $\mathrm{Zea}$ mays L.). Trends in Biosciences, 8 (10): 2468-2474.

\section{Aknowledgement:}

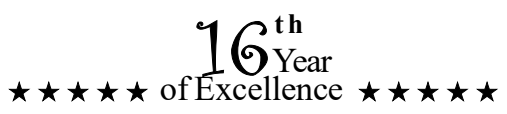

